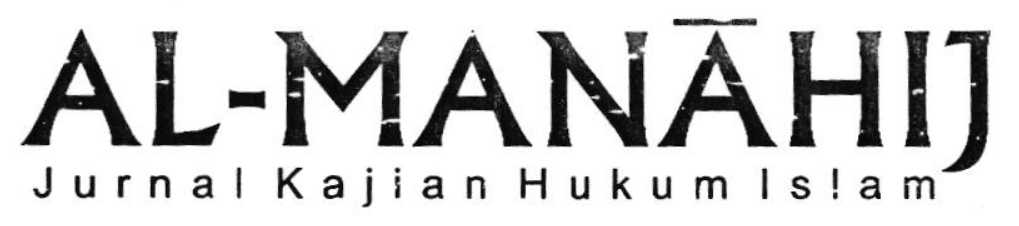




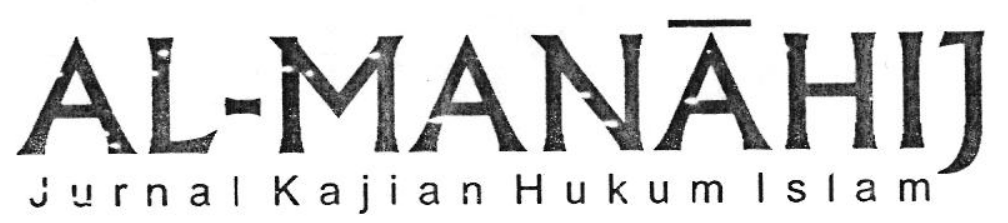

$\begin{array}{lll}\begin{array}{l}\text { Ketua Penyunting } \\ \text { Sekretaris Penyunting }\end{array} & : \text { Jamal Abdul Aziz } \\ \text { Anggota Penyunting } & : \text { H.M. Daelikhin } \\ & \begin{array}{l}\text { Ansori } \\ \text { A. Luthfi Hamidi } \\ \text { Ridwan } \\ \text { Suraji } \\ \text { Endang Widuri }\end{array} \\ & \begin{array}{l}\text { Supriyanto } \\ \text { Rina Heriyanti }\end{array} \\ \text { Editor Bahasa } & \begin{array}{l}\text { Siti Faizah Hidayati } \\ \text { Dyah Ratri Fiyani }\end{array}\end{array}$

\author{
Penerbit \\ Jurusan Syariah STAIN Purwokerto \\ Frekuensi Terbit \\ Duakalisetahun
}

Alamat Redaksi

Jurusan Syari'ah STAIN Purwokerto

J1. Jend. Ahmad Yani 40A Purwokerto 53126

Telp. (0281)635624 Fax. (0281)636553

Email: mal_dulaziz@yahoo.co.id

Al-Manähij adalah jurnal ilmiah Jurusan Syariah STAIN Purwokerto yang terbit dua kali dalam setahun. Jurnal ini memfokuskan pada kajian hukum Islam dalam berbagai sudut pandang keilmuan. Redaksi mengundang para ahli dan segenap civitas akademika untuk menulis artikel sesuai dengan tema besar jurnal ini. Artikel yang dimuat tidak selalu mencerminkam pandangan redaksi ataupun institusi lain yang terkait dengan penerbitan jurnal ini. 


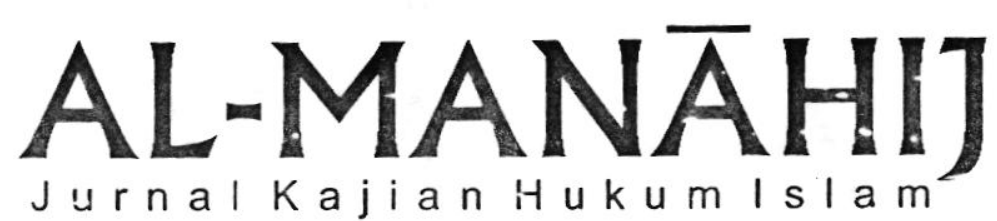

KONSEP NUSYUZ DALAM MAZHAB SYAFI'I

PERSPEKTIF KEADILAN GENDER

Dwi Meitayani 1

GRASI DALAM PERSPEKTIF HUKUM ISLAM

DAN HUKUM POSITIF INDONESIA

Imdadurrouf 23

GOOD GOVERNANCE DALAM PERSPEKTIF

HUKUM ISLAM

Arief Aulia Rachman 41

PELANGGARAN HAK KEKAYAAN INTELEKTUAL

DALAM PERSPEKTIF HUKUM ISLAM

Imam Mustofa 53

PORNOGRAFI DALAM PERSPEKTIF HUKUM ISLAM

DAN HUKUM POSITIF

Vivi Ariyanti 71

MENYOAL HUKUM MEROKOK

DALAM PERSPEKTIF HUKUM ISLAM

Muh. Mukri 91

MENUJU PENEGAKAN HUKUM

YANG LEBIH BERKEADILAN DAN RESPONSIF

Mub. Bachrul Ulum 113 


\title{
MENYOAL HUKUM MEROKOK DALAM PERSPEKTIF HUKUM ISLAM
}

\author{
Muh. Mukri*
}

\begin{abstract}
Ciggarette industry in Indonesia bas given much benefit to the country. Even our tobacco is classified as one the best tobacco in the world. However, from Islamic point of view it still becomes controverse. The benefit and the disadvantage of smoking, banning of smoking and analysis from MUI about smoking are discussed $n$ this paper.
\end{abstract}

Kata kunci: qiyas, istinbät al-aḅkām, maslaḅab

\section{A. Pendahuluan}

Salah satu hasil Ijtimak Ulama Komisi Fatwa se-Indonesia III di Padang Panjang, Sumatera Barat 23 hingga 26 Januari 2009 mengeluarkan fatwa soal hukum haramnya merokok bagi anak-anak, wanita hamil, dan di tempat umum. ${ }^{1}$

Jauh sebelumnya larangan merokok di tempat-tempat umum juga pernah diatur oleh pemerintah DKI Jakarta, seperti dalam PP. No.81 tahun 1999 tentang pengamanan rokok bagi kesehatan. Karena dinilai kurang efektif, peraturan tersebut kemudian diubah menjadi PP.No.19/2003 tentang kawasan tanpa rokok (KTR), yang

* Penulis adalah Dosen tetap IAIN Raden Intan Lampung.

${ }^{1}$ Majelis Ulamā' Indonesia, Ijmak Ulama: Keputusan Ijtimak Ulama Komisi Fatwa Se Indonesia III Tabun 2009 (Jakarta: MUI, 2009), hal. 56. 
disertai hukuman bagi yang melanggarnya berupa kurungan selama enam bulan plus denda 50 juta rupiah.

Pro-kontra menyelimuti fatwa kontroversial tersebut, terlebih daerah yang menjadi tempat tembakau berkembang dan tempat di mana perusahaan rokok berdiri. Di satu sisi ada yang setuju, namun di sisi lain banyak juga yang menolak. Di balik pro-kontra tersebut, ada fakta yang unik, ternyata sebagian ulama/kiai dalam MUI sendiri, dulunya adalah para pecandu berat rokok. Bahkan, kopi dan rokok masih menjadi "menu utama" di berbagai pesantren di Jawa. Setiap sowan di rumah kiai, pastilah kopi dan rokok menjadi "menu utama" sang kiai. Tanpa kopi dan rokok, mengaji dan belajar terasa hambar dan kurang sreg, serta inspirasi berkarya terasa tumpul. Inilah realitas di balik bilik pesantren di Jawa. Walaupun tidak semua, tetapi mayoritas mengakui demikian adanya ${ }^{2}$

Tentu saja reaksi itu dipicu oleh adanya berbagai kepentingan dari masing-masing orang. Bagi orang yang tidak merokok misalnya, fatwa ini tentu menjadi angin segar untuk menyelematkan udara dari polusi asap rokok. Karena asap rokok yang mengepul dapat mengancam kesehatan setiap orang yang menghisapnya. Dalam salah satu artikelnya, Edi Purwanto mencatat bahwa dari laporan sebuah lembaga yang bernama Morality From Smoking and Development Countries menyebutkan, sebanyak 3 juta orang dari berbagai kawasan dunia aklan meninggal setiap tahunnya karena asap rokok.

Sementara WHO menyebutkan bahwa rokok dapat menimbulkan berbagai penyakit kanker, seperti kanker paru-paru, kanker mulut, kanker bibir, kanker rahim, jantung, bronchitis, kematian mendadak pada bayi, bahaya rusaknya kesuburan bagi wanita dan impotensi bagi kaum pria, dan lain sebagainya. ${ }^{3}$ Melihat begitu besarnya potensi bahaya dalam rokok, tidak heran jika WHO kemudian memperkirakan pada tahun 2020 terdapat sekitar 50\% (sekitar 4,2 juta jiwa) akan mengalami kematian akibat tembakau,

\footnotetext{
${ }^{2}$ Muhammad Yunus, Kitab Rokek (Yogyakarta: Kutub, 2009), hal. 4.

${ }^{3}$ Ibid., hal. 23.
} 
terutama di wilayah Asia, khususnya di negara berkembang termasuk Indonesia.

Permasalahan rokok bukanlah masalah baru dalam pembahasan hukum Islam. Sudah lama para ulama terbelah pendapat mereka tentang status rokok ini, ada yang mengharamkan dan tidak sedikit yang meghalalkannya. Salah seorang tokoh Indonesia, Syaikh Iḥsān Jampes memberikan penjelasan lengkap tentang hukum rokok ini. Dengan bahasa yang renyah, Syeikh Iḥsān menjelaskan bahwa masyarakat Arab mengenal rokok dengan istilah al-dukhän, al-tabgh, al-tutun, dan Al-tinbäke. Nama itu sudah umum, sedangkan dalam istilah kedokteran, dikenal dengan istilah banbujjir. Secara historis, penulis menjelaskan bahwa tembakau (al-Tabgu) adalah tanaman lokal pada suata daerah bernama Tobago-suatu negeri di wilayah Meksiko, Amerika Utara. Karena tertarik, datanglah orang Eropa di Tobago, dan orang Eropa meniru kebiasan merokok orang Tobago.

Karena merasa asyik dan nikmat dengan merokok, pada 1560 M $(977 \mathrm{H})$, Yohana Pailot dari Vunisia mengunjungi Raja Alburqonal dari Panama, Amerika. Dia tidak sekedar berkunjung, tetapi juga memboyong bibit tembakau ke negerinya dan kemudian disebarluaskan ke Eropa secara massif. Dan orang Eropa menyebarkannya kepada seluruh dunia lewat proyek kolonialisasinya. Sementara, kopi dikenal dan dikonsumsi masyarakat Arab setelah dua generasi hijrah kenabian. Pada 1600 M (1017 H), kopi dibawa ke negeri-negeri Eropa dan kemudian disebarluaskan orang Eropa kepada seluruh penjuru dunia. ${ }^{4}$

Syeikh Ihsan juga menjelaskan status hukumnya. Mengkonsumsi kopi dan rokoh, sudah menjadi kontroversi ulama sejak abad ke-10 H. Dalam soal kopi, ulama yang mengharamkan kopi melihat bahwa di dalam kopi terdapat madarrät (kerusakan) kalau kita mengkonsumsinya. Pendapat ini didukung Syeikh Abtawi dari Syria, Syeikh Ibnu Sulțan, dan Syeikh al-Shanbaṭi dari Mesir. Sementara,

${ }^{4}$ Syaikh Ihsan Jampes, Kitab Kopi dan Rokok, terj. Ali Murtdho dan Mahbub Dje (Yogyakarta: LKiS, 2009), hal. 14-16. 
yang memperbolehkan kopi berpendapat bahwa kopi bisa menyegarkan, meringankan pikiran, dan membangkitkan semangat tetap terjaga sampai waktu yang lama untuk beribadah. Pendapat ini didukung Imām al-Ramli, Najm al-G̣äzi, dan Ibn Ḥajar al-Haytami. ${ }^{5}$

\section{B. Pro dan Kontra Hukum Rokok}

\section{Pendapat yang Mengharamkan Rokok}

Segolongan ulama telah menyatakan bahwa hukum merokok adalah haram. Ulama yang mengharamkan rokok berpendapat bahwa rokok merusak kesehatan, menyebabkan orang mabuk, tidak berkesadaran, baunya tidak disenangi orang lain, dan dipandang sebagai pemborosan (isbräf). Intinya, rokok membawa maḍarrāt yang bisa menghalangi ibadah. Pendapat ini dipegang oleh al-Qalyūbi, alLaqqāni, al-Bujairāmi, dan al-Syaranbila. ${ }^{6}$

Syaikh Shihāb al-Qalyūbi menjelaskan hukum merokok ini pada Bāb najis dalam ḥāshiyah-nya atas kitab karangan Jalāl al-Din al-Mahalli yang mengomentari kitab al-Minhäj-nya Imām Nawawi. Setelah al-Qalyūbi menerangkan bahwa setiap benda cair yang memabukkan, seperti arak dan sejenisnya, adalah najis. Ia menyatakan: ${ }^{7}$

Tiap-tiap benda beku (non cair) yang mengandung unsur melalaikan (تخدير ) dan menutupi ( تغطية ) bagi akal, adalah suci walaupun haram dimakan, yang demikian itu sebagaimana yang dikatakan oleh beberapa guru kami bahwa rokok termasuk barang yang diserupakan dengan candu. Jadi tembakau (rokoknya) tetap suci, namun haram digunakan. Sebab salah satu efek rokok adalah membuka saluran tubuh sehingga mempermudah masuknya penyakit berbahaya ke dalam tubuh. Oleh sebab itulah, merokok kerap kali menimbulkan lesu dan sesak nafas, ataupun gejala lain yang sejenis. Bahkan sumber yang dapat

${ }^{5}$ Ibid., hal. 22.

${ }^{6}$ Ibid., hal. 48-49.

${ }^{7}$ Ibid., hal. 22. 
dipercaya menyatakan bahwa sesungguhnya merokok dapat menimbulkan perasaan kepala berputar alias puyeng.

Dari kalangan fukaha mazhab Hanbali yang memberikan komentar tentang hukum merokok ini adalah al-Shaikh Mustafa alRahibani yang berkata:

Tiap-tiap mazhab yang empatitu ada yang mengharamkannya, ada yang memakruhkannya, yang membolehkannya, tetapi kebanyakan dari mazhab Syāfi'i dan mazhab Hanafi mereka berpendapat hukumnya mubah atau makruh, sebagian dari mereka berpendapat haram, dan kebanyakan dari kalangan mazhab Maliki mengharamkannya, dan sebagian dari mereka memakruhkannya. Begitu juga sahabat-sahabat kami, terutamanya ulama Najd, kami tidak melihat mereka menulis dengan nyata keharaman merokok itu.

Yang pasti, alasan-alasan lain yang dikemukakan untuk menghukumi haram terhadap rokok adalah, bahwa rokok memang sesuatu yang tidak ditemukan di zaman nabi. Akan tetapi agama Islam telah menurunkan naṣs-nașs yang universal atas semua hal yang membahayakan diri atau mencelakakan orang lain dan menghamburhamburkan harta, adalah hal yang diharamkan. Berikut adalah dalildalil yang mengharamkan rokok:

1. Menyebabkan kebinasaan. Para dokter bersepakat mengenai bahaya merokok, dan telah dipahami dalam syariat Islam bahwa segala sesuatu yang membahayakan adalah haram ${ }^{8}$.

2. Merokok berarti menghamburkan dan menyia-nyiakan harta, padahal syarak telah melarang dari menghamburkan dan menyianyiakan harta bukan pada tempatnya. Dalam naṣs fiqh yang muktabarah dinyatakan, bahwa menggunakan atau mengkonsumsi makanan yang menimbulkan bahaya adalah haram hukumnya. Apalagi mengkonsumsi rokok yang jelas-jelas diketahui pengaruhnya.

${ }^{8}$ Abdul Karim Muhammad Nașr, Rokek Haram, terj. Ahmad Nur Kholis (Yogyakarta: Citra Risalah, 2008), hal. 26. 


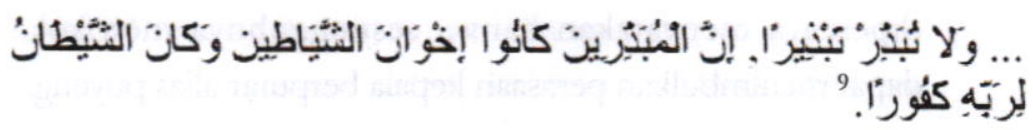

3. Rokok merupakan salah satu bahan konsumsi yang jelek dan berbau tidak sedap. Firman Allah: ${ }^{10}$

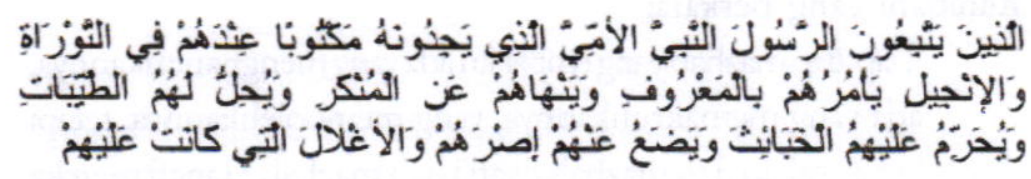

Syaikh Yūsuf Qarḍāwi dalam bukunya al-Halāl wa al-Harāam sebagaimana dikutip Luthfi Assyaukanie, memberikan fatwa haramnya hukum merokok berdasarkan adanya unsur kbabä'ith (yang jelek-jelek). Unsur khabaìith ini diakibatkan bukan cuma oleh faktor materialnya saja, tetapi juga oleh faktor-faktor lain yang menjadikannya khabā'ith. Qarḍāwi melihat bahwa rokok selain dapat merusak kesehatan juga dapat "merusak kantung". Merusak kantung ini lebih jauh lagi diartikan sebagai tindakan penghambur-hamburan harta (mubazir). Dan dengan alasan mubazir saja, rokok itu bisa menjadi haram. ${ }^{11}$

4. Merokok melemahkan badan dan menghilangkan akal. Tubuh kita pada dasarnya adalah amanah dari Allah yang harus dijaga. Padahal dalam Islam kita diajarkan untuk menjaga akal dan pikiran kita (bifz al-'aq). Mengkonsumsi barang-barang yang bersifat mengganggu fungsi raga dan akal hukumnya haram, misalnya alkohol, ganja dan sebangsanya. Perhatikan firman Allah: ${ }^{12}$

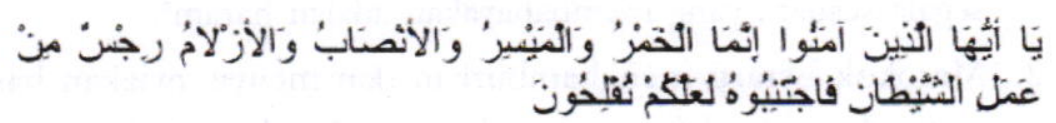

5. Menurut Quraisy Shihab, Majlis Ulama Indonesia (MUI) dalam musyawarah Nasional (MUNAS) tahun 1983 merumuskan

${ }^{9}$ QS. Al-Isrā': 26-27.

${ }^{10} \mathrm{Al}$-A'rāf: 157.

${ }^{11}$ Luthfi Assyaukanie, Politik, HAM, dan Isu-Isu Teknologi dalam Fikib Kontemporer (Bandung: Pustaka Hidayah, 1998), hal. 190.

${ }^{12}$ Al-Māidah (5): 90. 
"Kesehatan sebagai ketahanan jasmaniah, ruhaniah dan sosial yang dimiliki oleh manusia sebagai karunia Allah yang wajib disyukuri dengan mengamalkan tuntunan-Nya, dan memelihara serta mengembangkannya." Memang banyak sekali tuntunan agama yang merujuk kepada ke tiga jenis kesehatan tersebut. Dalam kontek kesehatan fisik misalnya ditemukan Sabda Nabi Muhammad SAW: Sesunggubnya badanmu mempunyai bak atas dirimu. Demikian juga ketika Nabi Muhammad SAW menegur sahabatnya yang bermaksud melampui batas dalam beribadah, sehingga kebutuhan jasmaniahnya terabaikan dan kesehatannya terganggu. Pembicaraan literatur keagamaan tentang kesehatan fisik dengan meletakkan prinsip: Pencegaban itu lebib baik dari pada pengobatan. Tidak merokok merupakan salah satu usaha pencegahan terhadap penyakit. Karena itu, dalam kontek kesehatan ditemukan sekian banyak petunjuk Kitab Suci dan Sunah Nabi SAW yang pada dasarnya mengarah pada upaya pencegahan. Salah satu sifat manusia yang secara tegas dicintai Allah adalah menjaga kebersihan. Kebersihan digandengkan dengan taubat. Sebagaimana disebutkan dalam al-Qur'an: ${ }^{13}$

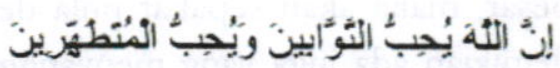

6. Bahaya yang ditimbulkan rokok lebih besar dari pada manfaatnya, bahkan rokok sedikitpun tidak mengandung manfaat. Ketika menjelaskan tentang hamr dan judi, Allah berfirman: ${ }^{14}$

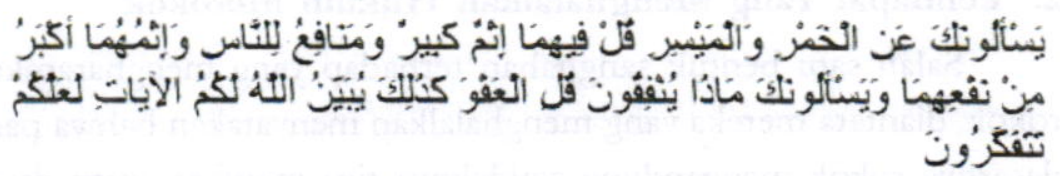

Pada dasarnya terdapat naṣs bersifat umum yang menjadi patokan hukum, yakni larangan melakukan segala sesuatu yang dapat membawa kerusakan, kemudaratan atau kemafsadatan sebagaimana termaktub di dalam al-Qur'an dan sunnah.

${ }^{13} \mathrm{Al}-\mathrm{Baq} a r a h(2): 222$.

${ }^{14} \mathrm{Al}$-Baqarah (2): 219. 


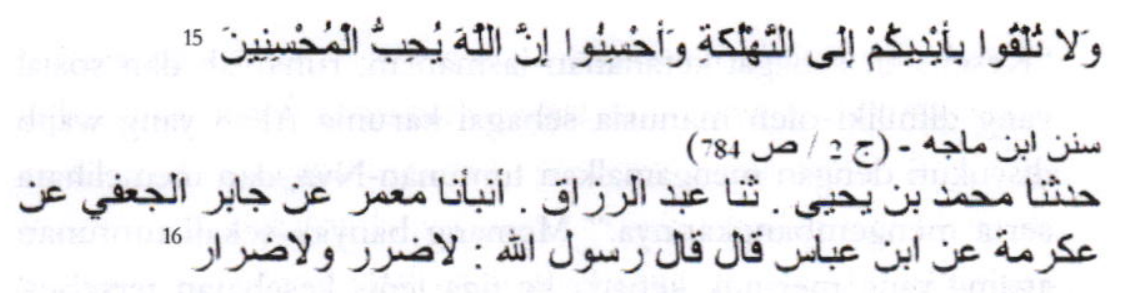

Bertolak dari dua nașs di atas, ulama sepakat mengenai segala sesuatu yang membawa mudarat adalah haram. Akan tetapi yang menjadi persoalan adalah apakah merokok itu membawa mudarat ataukah tidak, dan terdapat pula manfaat ataukah tidak. Dalam hal ini tercetus persepsi yang berbeda dalam meneliti dan mencermati substansi rokok dari aspek kemaslahatan dan kemafsadatan. Perbedaan persepsi ini merupakan babak baru munculnya beberapa pendapat mengenai hukum merokok dengan berbagai argumennya.

Seandainya semua sepakat, bahwa merokok tidak membawa mudarat atau membawa mudarat tetapi relatif kecil, maka semua akan sepakat dengan hukum mubah atau makruh. Demikian pula seandainya semuanya sepakat, bahwa merokok membawa mudarat besar, maka akan sepakat pula dengan hukum haram. Walaupun demikian ada juga yang menyanggah keharaman rokok, meskipun ada dalil yang telah memperkuat argumen mereka yang mengharamkan.

\section{Pendapat Yang Menghalalkan Hukum Merokok}

Salah satu bentuk sanggahan terhadap yang mengharamkan rokok, diantara mereka yang menghalalkan menyatakan bahwa pada dasarnya rokok mengandung setidaknya tiga manfaat, yaitu dapat memperkuat syaraf, mengurangi kelembaban dan membunuh kumankuman yang ada pada badan.

${ }^{15}$ Al-Baqarah (2): 195.

${ }^{16}$ Ibn Mājah, Sunan Ibn Mājab (Ttp.: 'Isā al-Bābỉ al-Ḥalabi wa Awlāduh, t.t), II: $784 .$. Bisa dilihat juga Sharaf al-Din al-Nawawi, Hadis al-Arba in al-Nawawiyyah (Surabaya: Salim Nabhan, t.t.), hal. 87. 
Beberapa pendapat itu serta argumennya dapat diklasifikasikan menjadi tiga macam hukum: Pertama, hukum merokok adalah mubah atau boleh karena rokok dipandang tidak membawa mudarat. Secara tegas dapat dinyatakan, bahwa hakikat rokok bukanlah benda yang memabukkan. Kedua, hukum merokok adalah makruh karena rokok membawa mudarat relatif kecil yang tidak signifikan untuk dijadikan dasar hukum haram. Ketiga, hukum merokok adalah haram karena rokok secara mutlak dipandang membawa banyak mudarat. Berdasarkan informasi mengenai hasil penelitian medis, bahwa rokok dapat menyebabkan berbagai macam penyakit dalam, seperti kanker, paru-paru, jantung dan lainnya setelah sekian lama membiasakannya.

Tiga pendapat di atas dapat berlaku secara general, dalam arti mubah, makruh dan haram itu bagi siapa pun orangnya. Namun bisa jadi tiga macam hukum tersebut berlaku secara personal, dengan pengertian setiap person akan terkena hukum yang berbeda sesuai dengan apa yang diakibatkannya, baik terkait kondisi personnya atau kwantitas yang dikonsumsinya. Tiga tingkatan hukum merokok tersebut, baik bersifat general maupun personal terangkum dalam paparan panjang 'Abdur Rahmān ibn Muhammad ibn Husain ibn 'Umar Ba'alāwiy di dalam Bughyah al-Mustarsyidin sebagai berikut: ${ }^{17}$

Tidak ada hadis mengenai tembakau dan tidak ada atsar (ucapan dan tindakan) dari seorang pun di antara para shahabat Nabi SAW. ... Jelasnya, jika terdapat unsur-unsur yang membawa mudarat bagi seseorang pada akal atau badannya, maka hukumnya adalah haram sebagaimana madu itu haram bagi orang yang sedang sakit demam, dan lumpur itu haram bila membawa mudarat bagi seseorang. Namun kadangkala terdapat unsur-unsur yang mubah tetapi berubah menjadi sunnah sebagaimana bila sesuatu yang mubah itu dimaksudkan untuk pengobatan berdasarkan keterangan terpercaya atau pengalaman dirinya bahwa sesuatu itu dapat menjadi obat untuk penyakit yang

${ }^{17}$ Husain ibn 'Umar Ba'alawì, Bugyab al-Mustanyidìn (Beirut: Dār al-Fikr, 1995), hal. 160. 
diderita sebagaimana berobat dengan benda najis selain khamr. Sekiranya terbebas dari unsur-unsur haram dan mubah, maka hukumnya makruh karena bila terdapat unsur-unsur yang bertolak belakang dengan unsur-unsur haram itu dapat difahami makruh hukumnya.

Senada dengan pendapat di atas adalah uraian Maḥmūd Shaltūt di dalam al-Fatawa $\bar{a}$ dengan sepenggal teks sebagai berikut: ${ }^{18}$

Tentang tembakau ... sebagian ulama menghukumi halal karena memandang bahwasanya tembakau tidaklah memabukkan, dan hakikatnya bukanlah benda yang memabukkan, disamping itu juga tidak membawa mudarat bagi setiap orang yang mengkonsumsi. ...Pada dasarnya semisal tembakau adalah halal, tetapi bisa jadi haram bagi orang yang memungkinkan terkena mudarat dan dampak negatifnya. Sedangkan sebagian ulama lainnya menghukumi haram atau makruh karena memandang tembakau dapat mengurangi kesehatan, nafsu makan, dan menyebabkan organ-organ penting terjadi infeksi serta kurang stabil.

Demikian juga penjelasan Wahbah Az-Zuhailiy sebagai berikut: ${ }^{19}$

Masalah kopi dan rokok; penyusun kitab Al-'Ubab dari madzhab al-Shāfíi ditanya mengenai kopi, lalu ia menjawab: (Kopi itu sarana) hukum, setiap sarana itu sesuai dengan tujuannnya. Jika sarana itu dimaksudkan untuk ibadah maka menjadi ibadah, untuk yang mubah maka menjadi mubah, untuk yang makruh maka menjadi makruh, atau haram maka menjadi haram. Hal ini dikuatkan oleh sebagian ulama dari madzhab Hanbali terkait penetapan tingkatan hukum ini. Syaikh Mar'i ibn Yūsuf dari mazhab Hanbali,

${ }^{18}$ Mahmùd Shaltūt, al-Fatāwà (Kairo: Dār al-Syurūq, 1991), hal. 383-384.

${ }^{19}$ Wahbah al-Zuhayfi, al-Figh al-Islami wa Adillatub (Damaskus: Dār al-Fikr, 1989), VI: $166-167$. 
penyusun kitab Ghāyah al-Muntahā mengatakan: Jawaban tersebut mengarah pada rokok dan kopi itu hukumnya mubah, tetapi bagi orang yang santun lebih utama meninggalkan keduanya.

Meski banyak ulama yang tegas menyatakan bahwa rokok hukumnya haram, namun ada juga sebagian ulama yang membolehkan. Yang memperbolehkan mengatakan bahwa rokok tidak najis, atau menghilangkan kesadaran. Bahkan, rokok memberikan semangat baru dalam menjalani kehidupan. Bagi kelompok ini, sangat omong kosong mereka mengatakan rokok haram, baik zatnya, atau dengan mengkonsumsinya. Merokok adalah mubah (boleh). Pendapat ini disokong al-Ghani an-Nabilisi, al-Shabramalis, al-Sulțān, dan alBarmawi. Pendapat yang paling populer mengatakan bahwa merokok adalah makruh. Pendapat ini didukung al-Bājūri dan asy-Syarqāwi. Ada juga yang mengatakan merokok boleh saja tetapi hukum makruh tetap menyertainya. Ini pendapat al-Sa’íid Babāsil dan Ibn Musā alNasawi.

Semua status hukum yang dijelaskan tergantung atas illah alaḅkām (alasan penjatuhan status hukum) dari berbagai kasus yang ada. Baik yang mengharamkan dan mengharamkan selalu menyertai illat (alasan) hukumnya. Berarti, kalau illat itu tidak ada, sangat mungkin hukumnya akan relatif semua. Walaupun ulamā̄ yang mengharamkan tetap berkelit dengan berbagai argumentasi rasionalnya.

Sebagaimana yang dinyatakan oleh Syaikh Universitas alAzhār, Jād al-Ḥaqq 'Ali Jād al-Ḥaqq dalam fatwanya bahwa masalah menghisap rokok ini banyak dibahas oleh para ulama dengan melihat segi manfaat atau mudaratnya dengan hukum asalnya tanpa didapati dalam Qur'an atau sunnah. Aktifitas merokok ini belum ditemukan pada awal Islam melainkan pada awal abad ke $11 \mathrm{Hijrah}$ setelah lama di Barat, negeri Maghribi, Sudan, kemudian berkembang ke negeri-negeri lain.

Ada juga ulama yang mengambil pendapat dari Radd al-Mukhtār karangan Ibn 'Abidin dan mengatakan bahwa merokok hukumnya 
mubah dan mereka yang memberi fatwa tentang halalnya rokok diikuti oleh empat mazhab populer dalam hukum Islam. Al-Allāmah 'Abd al-Ghānīi al-Nablusi al-Ḥanafi dalam risalahnya mengatakan: Sesungguhnya (tentang perkara ini) tidak ada dalil syarik tentang hukum haramnya atau makruhynya, dan tidak tetap mabuknya ataupun melemahkannya di kalangan semua para penghisapnya sehingga menjadikannya haram atau makruh tahrim (pada sisi hukumnya), Oleh sebab itu masalah ini masuk dalam kaedah (usul al-fiqh) "asal (hukum) pada semua perkara adalah boleh.” Dan dalam kitab "Asybah" (karangan Imām al-Suyựii) termasuk ke dalam kaedah "asal (hukum) dalam semua perkara ialah boleh atau tawaqquf..."20

Ulama lainnya yang menghalalkan rokok adalah al-'Allāmah al-Shabramalis, Syaikh Sulțān al-Halāb, dan al-Barmāwì. AlBarmāwi mengutip kata-kata gurunya (al-Bābili) yang berkata, "Menghisap rokok hukumnya halal. Keharamannya bukan karena rokok itu sendiri haram (barām li żätibi), namun karena ada unsur dan faktor luar yang mempengaruhi atau merubah hukum halal ini”. Contoh unsur luar tersebut adalah bahaya yang timbul dan dipicu oleh rokok. $^{21}$

Begitu juga ulama-ulama atau kyai-kyai di Indonesia kebanyakan menghukumi halal merokok. Merokok tetap terus mereka lakukan, baik sebelum adanya fatwa atau sesudahnya. Karena itu, dikeluarkannya fatwa haram oleh MUI tetap tidak membuat mereka bergeming. Bahkan KH. Idris Marzuki dari Kediri, dengan terang-terangan menolak fatwa haramnya rokok sebagaimana fatwa MUI. "Agama Islam saja tidak mengharamkan rokok. Oleh karena itu tidak perlu MUI melarangnya dalam bentuk fatwa." 22

\footnotetext{
${ }^{20}$ Yünus, Kitab, hal. 62.

${ }^{21}$ Syaikh Ihsan Jampes, Kitab, hal. 55.

${ }^{22}$ Antara, Januari 2009.
} 


\section{Ulasan Terhadap Fatwa Haramnya Merokok}

Dalam pandangan penulis, sejarah awal kemunculan rokok sampai kini masih penuh kontoversi dan kesimpangsiuran termasuk hukumnya. Kiranya ada benang ruwet dan rumit yang dapat diurai dalam perbedaan pendapat yang terasa semakin sengit mengenai hukum merokok. Benang ruwet dan rumit itu adalah beberapa pandangan kontradiktif dalam menetapkan illab atau alasan hukum yang di antaranya akan diulas dalam beberapa bagian.

Pertama, sebagian besar ulama terdahulu berpandangan, bahwa merokok itu mubah atau makruh. Mereka pada masa itu lebih bertendensi pada bukti, bahwa merokok tidak membawa mudarat, atau membawa mudarat tetapi relatif kecil. Barangkali dalam gambaran kita sekarang, bahwa kemudaratan merokok dapat pula dinyatakan tidak lebih besar dari kemudaratan durian yang jelas berkadar kolesterol tinggi. Betapa tidak, sepuluh tahun lebih seseorang merokok dalam setiap hari merokok belum tentu menderita penyakit akibat merokok. Sedangkan selama tiga bulan saja seseorang dalam setiap hari makan durian, kemungkinan besar dia akan terjangkit penyakit berat.

Kedua, berbeda dengan pandangan sebagian besar ulamā' terdahulu, pandangan sebagian ulama sekarang yang cenderung mengharamkan merokok karena lebih bertendensi pada informasi (bukan bukti) mengenai hasil penelitian medis yang sangat detail dalam menemukan sekecil apa pun kemudaratan yang kemudian terkesan menjadi lebih besar. Apabila karakter penelitian medis semacam ini kurang dicermati, kemudaratan merokok akan cenderung dipahami jauh lebih besar dari apa yang sebenarnya. Selanjutnya, kemudaratan yang sebenarnya kecil dan terkesan jauh lebih besar itu (hanya dalam bayangan) dijadikan dasar untuk menetapkan hukum haram. Padahal, kemudaratan yang relatif kecil itu seharusnya dijadikan dasar untuk menetapkan hukum makruh.

Hal seperti ini kemungkinan dapat terjadi khususnya dalam membahas dan menetapkan hukum merokok. Tidakkah banyak pula 
makanan dan minuman yang dinyatakan halal, ternyata secara medis dipandang tidak steril untuk dikonsumsi. Mungkinkah setiap makanan dan minuman yang dinyatakan tidak steril itu kemudian dihukumi haram, ataukah harus dicermati seberapa besar kemudaratannya, kemudian ditentukan mubah, makruh ataukah haram hukumnya.

Ketiga, hukum merokok itu bisa jadi bersifat relatif dan seimbang dengan apa yang diakibatkannya mengingat hukum itu berporos pada illah yang mendasarinya. Di sini berlaku kaidah usul fikih: "Hukum itu tergantung pada ada atau tidaknya illat hukum (yang melingkupinya)."23

Dengan demikian, pada satu sisi dapat dipahami bahwa merokok itu haram bagi orang tertentu yang dimungkinkan dapat terkena mudaratnya. Akan tetapi merokok itu mubah atau makruh bagi orang tertentu yang tidak terkena mudaratnya atau terkena mudaratnya tetapi kadarnya kecil.

Keempat, kalaulah merokok itu membawa mudarat relatif kecil dengan hukum makruh, kemudian di balik kemudaratan itu terdapat kemaslahatan yang lebih besar, maka hukum makruh itu dapat berubah menjadi mubah. Adapun bentuk kemaslahatan itu seperti membangkitkan semangat berpikir dan bekerja sebagaimana biasa dirasakan oleh para perokok. Hal ini selama tidak berlebihan yang dapat membawa mudarat cukup besar. Apa pun yang dikonsumsi secara berlebihan dan jika membawa mudarat cukup besar, maka haram hukumnya. Berbeda dengan benda yang secara jelas memabukkan, hukumnya tetap haram meskipun terdapat manfaat apapun bentuknya karena kemudaratannya tentu lebih besar dari manfaatnya. Namun demi kesehatan dalam pandangan penulis tetap kemudaratan harus dijauhi. Termasuk dalam hal rokok ini, karena kaidah fikih menyatakan:

1. Kemudaratan harus dihilangkan (al-dararu yuzălu $)^{24}$

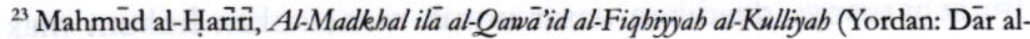
Imar, 1998), hal. 178.

${ }^{24}$ Abdurrahmān bin Abi Bakr as-Suyūịi, al-Asbbāb wa al-Nažă̄ir fí al-Furū' (Ttp.: Dār al-Fikr, t.t.), hal. 59. Lihat juga dalam Muhlis Usmān, Kaidab-kaidah Ușüliyah dan Fiqbiyah (Jakarta: Raja Grafindo Persada, 1996), hal. 132. 
2. Tidak boleh membuat kerusakan pada diri sendiri dan orang lain (lā darara wala dirār $)^{25}$

3. Menolak kerusakan lebih diutamakan daripada menarik kemaslahatan dan apabila berlawanan antara yang mafsadah dan maslahah maka yang didahulukan adalam menolak mafsadahnya. ${ }^{26}$

Dalam konteks itu, menurut penulis ada beberapa hal berikut perlu diketahui dan menjadi bahan renungan. Pertama, keharaman rokok tidak ditunjuk langsung oleh al-Qur'an dan Hadis, melainkan merupakan hasil produk penalaran dan ijtihad para pengurus MUI, sehingga bisa benar atau keliru. Dengan demikian, keharaman rokok tak sama dengan keharaman khamr. Jika haramnya meminum khamr bersifat manșūsah (ditunjuk langsung oleh teks al-Qur'an), ${ }^{27}$ maka keharaman merokok bersifat mustanbatah (hasil ijtihad para ulama). Menurut para ulama $u s \bar{u} l$ fiqh, kata haram biasanya digunakan untuk jenis larangan yang tegas disebut al-Qur'an dan Hadis. Sementara larangan yang tak tegas, tak disebut haram melainkan makrüh tahrim.

Kedua, yang menjadi causa hukum ('illat al-bukm)nya, demikian menurut ulama MUI, adalah karena merokok termasuk perbuatan yang mencelakakan diri sendiri. Rokok mengandung zat yang merusak tubuh. Dengan menggunakan mekanisme masälik al-illab dalam metode qiyās usūul fiqh, alasan mencelakan diri sendiri tak memenuhi syarat dan kualifikasi sebagai 'illah al-bukm. Ia terlalu umum (ghayr mundabit). Sebab, sekiranya mencelakan diri sendiri ditetapkan sebagai causa hukum, maka semua barang yang potensial menghancurkan tubuh bisa diharamkan. Gula yang dikon-

${ }^{25}$ Kaidah ini sebenarnya berasal dari hadis yang diriwayatkan oleh Ahmad dan Ibn Mājah dari ibn Abbās. Lihat dalam Fathurrahman Jamil, Filsafat Hukum Islam (Jakarta: Logos, 1997), hal. 66.

26 'Abd al-Rahmān ibn Abỉ Bakr al-Suyūụi, al-Asbbāh, hal. 62.

${ }^{27}$ Bunyi ayat: "Hai orang-orang yang beriman, Sesungguhnya (meminum) khamar, berjudi, (berkorban untuk) berhala, mengundi nasib dengan panah, adalah termasuk perbuatan syaitan. Maka jauhilah perbuatan-perbuatan itu agar kamu mendapat keberuntungan. QS. Al-Māidah (5): 90. 
sumsi dalam waktu lama bisa menimbulkan diabetes. Begitu juga makanan lain yang mengandung kolesterol tinggi bisa diharamkan karena akan menyebabkan timbulnya beragam penyakit. Karena itu, diperlukan keahlian sekaligus kehati-hatian dalam menentukan alasan hukum pengharaman sebuah tindakan. Para ahli usul fikih sepakat bahwa causa hukum sebuah perkara, di samping ditetapkan naṣṣ alQur'an dan Hadis, juga diputuskan oleh ulama yang telah memenuhi kualifikasi seorang mujtahid. Inilah yang dalam wacana usul fikih disebut masälike al-illah. Masälike al-illah, ialah cara atau metode yang digunakan untuk mencari sifat atau 'illat dari suatu peristiwa atau kejadian yang dapat dijadikan dasar untuk menetapkan hukum.

Di antara cara tersebut, ialah: naṣs yang menunjukkannya, ijmak yang menunjukkannya dan dengan penelitian yang meliputi: munäsabah, al-sabru wa taqsim, tanqüḥ al-manät dan tahqüq al-manät. ${ }^{28}$

Ketiga, merumuskan hukum (istinbät al-bukem) dan menerapkan hukum (tatbiq al-ḅukm) adalah dua subyek yang berbeda. Jika perumusan hukum membutuhkan perlengkapan teknis-intelektual untuk menganalisa dalil-dalil normatif dalam Islam, maka menerapkan hukum memerlukan analisis sosial-ekonomi-politik; apakah sebuah fatwa potensial menggulung sumber daya ekonomi masyarakat atau tidak, misalnya. Dari sini jelas bahwa mengharamkan rokok ketika kondisi perekonomian masyarakat lagi sekarat tak cukup bijaksana. Banyak orang yang setuju perihal pelarangan rokok. Namun, yang mereka tolak adalah fatwa pelarangan itu dikeluarkan disaat masyarakat dilanda krisis. Kita tahu, kondisi makro ekonomi Indonesia ambruk sebagai akibat lanjutan dari krisis yang berlangsung di hulu, Amerika Serikat. Begitu juga, sektor riil masih belum pulih ketika diterjang badai krisis tahun 1997.

Dengan alasan-alasan itu, penulis berharap para pengurus MUI meninjau ulang fatwa pengaharaman merokok. MUI perlu memeriksa kembali argumen pelarangannya yang belum kukuh sambil mencari momentum yang tepat untuk graduasi pembatasan merokok.

\footnotetext{
${ }^{28}$ Abd al-Wahhāb Khallaf, 'Ilm Ușül al-Figh (Kuwait: Dār al-Qalam, t.t), hal. 52-60.
} 
Terlepas dari adanya pro-kontra mengenai hukum rokok atau adanya ancaman kesehatan yang ditimbulkan darinya, rokok tetap saja menjadi bagian penting dari kehidupan sebagian masyarakat baik di Indonesia maupun negara-negara lainnya. Artinya, meski sudah ada fatwa, peraturan atau undang-undang yang dikeluarkan oleh pemerintah tentang larangan merokok, namun tetap saja ada yang melanggar dan menolak peraturan tersebut. Penolakan tersebut sesungguhnya didasari oleh berbagai alasan:

Pertama, karena mereka termasuk kelompok perokok aktif. Bagi prokok aktif, larangan merokok dinilai membatasi ruang gerak hidup mereka. Karena itu, seperti halnya mempertahankan hak hidup, larangan tersebut dirasa perlu untuk dilawan.

Kedua, karena mereka termasuk bagian dari alat produksi rokok, baik sebagai pengelola perusahaan, pemegang saham, maupun buruh yang bekerja dalam perusahaan rokok. Bagi mereka, larangan ataupun fatwa haram merokok merupakan ancaman yang paling besar. Sebab, hal itu akan menyebabkan mereka kehilangan pekerjaan.

Ketiga, karena pertimbangan mengenai dampak social dan ekonomi yang ditimbulkannya, baik bagi masyarakat umum maupun bagi pendapatan Negara. Mereka ini sebenarnya bukan seorang prokok, bukan pula bagian dari alat produksi rokok. Melainkan pemerhati atas fenomena-fenomena sosial.

Keyakinan mereka bahwa fatwa itu akan menimbulkan dampak-dampak negatif menyebabkan mereka mengambil sikap dengan cara menolaknya. Atau setidaknya mengajak semua pihak supaya berfikir lebih realistis menyangkut masalah rokok. Hal ini dilakukan karena dampak yang diakibatkannya terbilang cukup fatal. Seperti ancaman pengangguran jika akhirnya perusahaan rokok tempat mereka bekerja terpaksa gulung tikar. Di samping itu, petani tembakau, penjual asongan rokok dan sebagainya, yang juga akan terancam kehilangan lapangan pekerjaan. Seperti yang kita tahu di Indonesia lapangan pekerjaan masih teramat sempit dan sulit. Sehingga jika banyak perusahaan rokok gulung tikar, maka dapat 
kita prediksi negeri ini akan lebih banyak disesaki oleh masyarakat pengangguran. Dan bila kondisi semacam ini benar-benar terjadi tentu sama artinya dengan melakukan pembunuhan massal dengan cara perlahan-lahan.

Selain dampak di atas, dampak lain yang ditimbulkan dari larangan merokok adalah dapat mengurangi tingkat pendapatan negara. Selama ini cukai yang disumbangklan oleh rokok terhadap negara terhitung besar, yaitu Rp. 9 miliar per hari. Maka dengan munculnya fatwa dan larangan merokok, tentu pemasukan untuk negara menjadi berkurang. Dan sudah bisa kita pastikan rakyatlah yang akan menjadi korbannya, padahal kebijakan negara terhadap rakyatnya harus didasari oleh kemaslahatan berdasarkan kaidah: "Suatu tindakan/peraturan pemerintah, berintikan terjaminnya kemaslahatan rakyatnya." 29

Ini artinya merokok dan produksi rokok masih membawa manfaat yang besar bagi negara kita, sementara mudaratnya masih belum begitu jelas. Kalau merujuk kepada konsep maslaḥab alGhazāil yang memberikan defenisi bahwa maslạah adalah menarik manfaat atau menolak mudarat (hal-hal yang merugikan) maka produksi dan merokok adalah mubah. ${ }^{30}$ Apalagi fatwa yang dikeluarkan MUI tidak bersifat kulli (seluruh masyarakat) tetapi bersifat $j u z^{i} i$ yaitu untuk anak-anak dan perempuan hamil. Begitu juga kalau permasalahan rokok ini kita qiyaskan kepada hamar maka 'illatnya tidak munāsib atau berkecocokan. Menurut al-Ghazāli kriteria untuk menentukan atau kelayakan (munäsabab) adalah keterkaitannya dengan kemaslahatan. Menjelaskan ini ia mengatakan, "Arti kesesuaian tersebut adalah bahwa 'illab (alasan) dimaksud, dilihat dari segi kemaslahatan, memang menghendaki ditetapkannya hukum bersangkutan;" dan "al-wasf al-munāsib adalah suatu alasan yang didasarkan kepada kemaslahatan." 31

\footnotetext{
${ }^{29}$ Al-Suyưự, Al-Ashbāh., hal. 175.

${ }^{30}$ Al-Ghazāil, al-Mustasfa, hal. 286.

${ }^{31}$ Syamsul Anwar, "Teori Konformitas dalam metode penemuan Hukum Islām alGazzali" dalam Amin Abdullah dkk, Antologi Studi Islam Teori dan Metodologi (Yogyakarta: Sunan Kalijaga Press, 2000), hal. 274.
} 


\section{Penutup}

Persoalan rokok memang tak ubahnya seperti pisau bermata dua. Di satu sisi, jika ia telah beredar maka dapat menimbulkan ancaman cukup besar bagi kesehatan manusia dan agama mewajibkan kepada kita untuk menjaga kesehatan. Namun di sisi lain jika peredarannya dilarang maka akibatnya pun akan lebih besar lagi. Jika dua kemudaratan terjadi dalam kasus hukum maka yang lebih ringan madaratnya yang didahulukan. Persoalannya, pada sisi mana kita harus berpijak? Kemaslahatan yang mana harus didahulukan. Lagi-lagi semuanya harus dikembalikan pada diri kita masing-masing. Apakah merokok itu membawa mudarat bagi kita atau tidak. 


\section{DAFTAR PUSTAKA}

Anwar, Syamsul. "Teori Konformitas dalam Metode Penemuan

Hukum Islam al-Ghazali." Dalam Amin Abdullah dkk., Antologi Studi Islam: Teori dan Metodologi. Yogyakarta: Sunan Kalijaga Press, 2000.

Assyaukanie, Luthfi. Politik, HAM, dan Isu-Isu Teknologi dalam Fikih Kontemporer. Bandung: Pustaka Hidayah, 1998.

Ba'alāwi, Husayn ibn 'Umar. Bugbyah al-Mustarshidinn. Beirut: Dār alFikr, 1995.

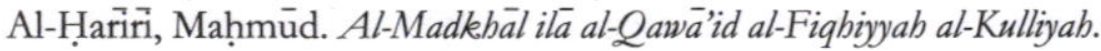
Yordan: Dār al-'Imār, 1998.

Jamil, Fathurrahman. Filsafat Hukum Islam. Jakarta: Logos, 1997.

Jampes, Syaikh Ihsan. Kitab Kopi dan Rokok, terj. Ali Murtdho dan Mahbub Dje. Yogyakarta: LKiS, 2009.

Khallāf, 'Abd al-Wahhāb. Tlm Ușūl al-Fiqh. Kuwait: Dār al-Qalam, t.t.

Mājah, Ibn. Sunan Ibn Mājah, 2 jilid. T.tp: 'Isa al-Bābi al-Ḥalabì wa Awladuh, t.t.

Nașr, Abdul Karim Muhammad. Rokok Haram, terj. Ahmad Nur Kholis. Yogyakarta: Citra Risalah, 2008.

Al-Nawāwi, Sharaf al-Din. Hadis al-Arba'in al-Nawawiyyah. Surabaya: Salim Nabhan, t.t.

Shaltūt, Mahmūd. Al-Fatāwāa . Kairo: Dār al-Syurūq, 1991.

Al-Suyūti, Abdurrahmān bin Abi Bakr. Al-Ashbah wa al-Nažàir fí al-Furū' Beirut: Dār al-Fikr, 1995.

Usman, Muhlis. Kaidah-Kaidah Usuliyah dan Fiqbiyah. Jakarta: Raja Grafindo Persada, 1996.

Yunus, Muhammad. Kitab Rokok. Yogyakarta: Kutub, 2009. 
Al-Zuhayli, Wahbah. Al-Fiqh al-Istämi wa Adillatuh, 9 jilid. Damaskus: Dār al-Fikr, 1989.

Majelis Ulamā' Indonesia. Ijmak Ulama: Keputusan Ijtimak Ulama Komisi Fatwa Se Indonesia III Tabun 2009. Jakarta: MUI, 2009. 
Muh. Mukri 